\title{
Study the Biochemical Correlation of Insulin Resistance with HbA1c and Sex Hormones in NIDDM Patients/Meisan-Iraq
}

\author{
Adnan J. M. Al-Fartosy, Ibrahim M. Mohammed \\ Department of Chemistry, College of Science, University of Basra, Basra, Iraq \\ Email: dr.adnanfrtosy@yahoo.com
}

How to cite this paper: Al-Fartosy, A.J.M. and Mohammed, I.M. (2017) Study the Biochemical Correlation of Insulin Resistance with HbAlc and Sex Hormones in NIDDM Patients/Meisan-Iraq. Journal of Diabetes Mellitus, 7, 302-315.

https://doi.org/10.4236/jdm.2017.74025

Received: August 7, 2017

Accepted: November 13, 2017

Published: November 16, 2017

Copyright (c) 2017 by authors and Scientific Research Publishing Inc. This work is licensed under the Creative Commons Attribution International License (CC BY 4.0).

http://creativecommons.org/licenses/by/4.0/

\begin{abstract}
Objective: The association between type 2 diabetes mellitus and certain endocrine disorders has the paucity of information and limited data in the province of Meisan (southern of Iraq). Hence, in the present study, an attempt was made to investigate the levels of plasma $\mathrm{HbAlc}$, serum insulin resistance and levels of serum sex hormones in men and women of control and type 2 diabetic patients. Also, the present study aimed to explored the correlation coefficient ( $r$ ) between insulin resistance and level of $\mathrm{HbAlc}, \mathrm{FSH}, \mathrm{LH}, \mathrm{Tt}$, progesterone and estradiol in men and women patients with NIDDM. Methods: One hundred Iraqi volunteers with abdominal obesity were selected in the present study. Fifty diabetic patients with NIDDM (26 men, and 24 women) aged between (37) and (65) years and 50 healthy individuals ( 25 men, and 25 women) aged between (36) and (65) years considered as control group. Complete medical history was taken from each subject and complete clinical examinations were performed for all volunteers. Then, the two groups were matched for their fasting blood sugar, BMI, insulin hormone; c-peptide, $\mathrm{HbAlc}$, sex hormones and insulin resistance parameters (HOMA2-IR, HOMA\%B and HOMA\%S) were calculated using HOMA2 calculator software. Results: We found that insulin resistance demonstrated negative correlations ( $\mathrm{p}<0.05$ ) with levels of serum follicle stimulating hormone (FSH), luteinizing hormone ( $\mathrm{LH})$, total testosterone, progesterone and estradiol. While, there was a positive and significant correlation $(\mathrm{p}<0.01)$ with value of HbA1c in men and women NIDDM patients. Conclusion: We conclude that an increase in the level of insulin resistance is associated with increased level of blood HbA1c and decreased in level of serum sex hormones (FSH, LH, Tt, E2 and progesterone) in men and women of diabetic group. These behaviors might suggest that insulin resistance can be used as a potential biomarker for predicting dysfunction of sex hygiene in NIDDM patients in addition to glycemic control.
\end{abstract}




\section{Keywords}

Insulin Resistance, Biochemical Correlation, HbA1c, Sex Hormones, NIDDM

\section{Introduction}

Diabetes mellitus is a group of metabolic disorders in which a person has hyperglycemia, which may be due to the insulin secretion is not enough, or because tissue cells do not respond to the insulin that is produced from pancreatic $\beta$-cells [1]. Non-insulin dependent diabetes mellitus is characterized by high plasma glucose in the context of insulin resistance and relative insulin deficiency [2]. At the present time there are more than $90 \%$ of diabetic patients are NIDDM diabetics and it is reported to be associated with certain endocrine disorders, in particular hypogonadism [3]. Several observational studies have reported an association of insulin resistance with levels of serum sex hormones in patients with NIDDM [4]. Insulin resistance (IR) is the reducing of biological effects (glucose assimilation) in tissues and organs to the answer for insulin action on the specific cell receptors. It can be divided into three levels. Also, it can develop on pre-receptor level: Disorder of pancreas $\beta$-cell function; cell level: decreasing of tissue insulin sensitivity; liver level: increasing of glucose production. As it is known, $\beta$-cell function, secreting insulin, especially clear reveals under the glucose-tolerant test. The sensitivity of s-cells to glucose is most important quantitative parameter of their functional capacity [5]. However, levels of sex hormone binding globulin (SHBG) may be associated with the risk of NIDDM and are strongly associated with insulin resistance [6]. It has been reported that in NIDDM patient's level of serum testosterone may be accompanied by normal luteinizing hormone (LH) and follicle-stimulating hormone (FSH) and sexual function may be preserved in some patients. In addition to aging, diabetes mellitus has also been associated with hypothalamic-pituitary-gonadal (HPG) axis suppression. When the primary source of gonadal failure resides in the testicles, the pituitary, or the hypothalamus, the ultimate result is diminished serum testosterone concentration. Inadequate production of testosterone may cause various complications such as osteoporosis and diminished level of physical and emotional energy [7]. Chronic hyperglycemia causes increased glycation of protein including hemoglobin resulting in the formation of advanced glycated and products ${ }^{[8]}$. On the other hand, it has been suggested that in the diabetic patients a positive correlation between increased serum ferritin and poor glycaemic control reflected by higher HbAlc [9]. As there was paucity of information and limited data on the association between type 2 diabetes mellitus and certain endocrine disorders in the province of Meisan (southern of Iraq). Hence, in the present study, an attempt was made to investigate the levels of plasma HbAlc, serum insulin resistance and levels of serum sex hormones in men and women of control and type 2 diabetic patients. Also, the present study aimed to explored 
the correlation coefficient $(\mathrm{r})$ between insulin resistance and level of $\mathrm{HBAl}_{\mathrm{C}}$, FSH, LH, Tt, progesterone and estradiol in men and women patients with NIDDM.

\section{Material and Method}

\subsection{Subjects}

This study was carried out on peoples who suffering from NIDDM patients in Meisan province. The study samples included (50) patients suffering from type II of diabetes (26 men and 24 women) aged between (37) and (65) years, and controlled with (50) healthy individuals ( 25 men and 25 women) aged between (36) and (65) years. All the subjects gave their informed consent and a semistructured questionnaire was used to obtain information about age, duration of diabetes, health habits (smoking, consumption of alcohol and exercise), and history of medical and current medications. Individuals should not belong to the class of secondary diabetes due to pancreatic diseases, hormonal abnormalities, drug induced, genetic syndromes and those who used exogenous hormone, opium or medication which might affect sex hormone level were excluded from the study...etc. The control group was health Individuals; not suffering from type-2 diabetes nor having any family history of NIDDM; not suffering from any acute or chronic cardiovascular diseases; not taking any drug believed to alter plasma glucose level.

\subsection{Samples}

The studied samples of patients were collected from the central laboratory of Al-Sadder General Hospital and Diabetes and Endocrine Center at the province of Meisan. All blood samples were obtained in the morning between 08:00 and 09:00 hours after a 12-h fast and a 30-min of rest in the supine position. Blood samples were collected from the antecubital vein. Rubber tourniquet was applied for less than one minute and the site to be punctured cleaned with $70 \%$ methylated spirit. A single blood sample was collected from each subject. About $10 \mathrm{ml}$ of blood was taken. One $\mathrm{ml}$ of blood was placed into EDTA vacutainer tube to perform $\mathrm{HbAlc}$ for cases and controls. The rest of the blood samples were placed in plain tubes and allowed to clot. After the blood had clotted it was placed in a centrifuge and spun at $402 \mathrm{x}$ g for 10 minutes to obtain the sera. The obtained sera immediately use in detection of variables in this study, and others were stored in deep freezing at $\left(-20^{\circ} \mathrm{C}\right)$ until using.

\subsection{Methods}

\subsubsection{Measurement of Insulin Resistance Parameters}

Insulin resistance parameters (insulin resistance (HOMA2-IR), beta cell activity (HOMA\%B) and insulin sensitivity (HOMA\%S)) were calculated from fasting insulin and fasting blood glucose (FBG) using HOMA2 calculator software.

\subsubsection{Methods of Biochemical Estimation}

The control and NIDDM patients blood samples were analyzed for biochemical 
parameters by standard procedures as follows: Serum glucose was estimated by kit (Randox/England) [10], serum insulin was estimated by kit (demeditec/ Germany) [11], blood HbAlc was estimated by kit (STANBIO/Germany) [12], and serum follicle stimulating hormone (FSH) [13], luteinizing hormone (LH) [14], testosterone [15], progesterone [16] and estradiol [17] was estimated by direct method using reagent kit (Human/Germany).

\subsection{Statistical Analysis}

Statistical analysis of data was carried out using statistical package for the social sciences (SPSS) and the values expressed as mean \pm SD. Correlations between were determined using Pearson correlation. The values of $\mathrm{p}<0.05, \mathrm{p}<0.01$ was considered as significant differences.

\section{Results}

\subsection{Basic Characteristics of Individuals in the Present Study}

One hundred of subjects were included in the present study. 50 patients with type $2 \mathrm{DM}$ and 50 healthy individuals considered as control group. The general characteristics of all subjects participated in the present study were presented in (Table 1).

\subsection{Study the Insulin Resistance Parameters}

Data obtained in the present study, show a significant increase in IR level (4.24 \pm 0.57 vs $1.36 \pm 0.23$ and $4.31 \pm 59$ vs $1.18 \pm 0.13, \mathrm{P}<0.05)$ respectively, in men and women type 2 diabetic patients compared to control. Also, Insulin/Glucose ratio was significantly $(\mathrm{P}<0.05)$ higher in men and women type 2 diabetic patients compared to control ( 0.152 vs 0.093 and 0.164 vs 0.083 , respectively). Furthermore, there was no significant difference between HOMA\%B \pm level of cases and controls. Moreover, level of $\mathrm{HOMA} \% \mathrm{~S} \pm$ was significantly lower in cases compared to controls, as shown in (Table 2).

Table 1. The demographic characteristics of the study.

\begin{tabular}{cccc}
\hline The characteristics & & Healthy control & Type 2 DM. \\
\hline Total (No.) & & 50 & 50 \\
Age (mean \pm SD) & & $51.66 \pm 7.72$ & $52.37 \pm 6.46$ \\
Sex & Male & 25 & 26 \\
& Female & 25 & 24 \\
DM. duration (mean \pm SD) & $\leq 10$ & & 32 \\
& $>10$ & & 18 \\
Smoking habit & Negative & 26 & 49 \\
& Positive & 4 & 1 \\
\hline
\end{tabular}


Table 2. Study the insulin resistance parameters. The values are the Mean \pm SD.

\begin{tabular}{cccccc}
\hline \multirow{2}{*}{ Parameters } & \multicolumn{2}{c}{ Type 2 DM } & \multicolumn{2}{c}{ Healthy Control } & \multicolumn{2}{c}{ Significance p-value } \\
\cline { 2 - 5 } & men & women & men & women & HS \\
\hline Glucose $(\mathrm{mg} / \mathrm{dl})$ & $189.42 \pm 15.18$ & $180.21 \pm 16.38$ & $108 \pm 9.2$ & $106 \pm 8.3$ & $\mathrm{~S}$ \\
Insulin $(\mu \mathrm{u} / \mathrm{ml}) \pm \mathrm{SD}$ & $28.85 \pm 3.77$ & $29.65 \pm 4.06$ & $10.08 \pm 1.66$ & $8.81 \pm 0.99$ & $\mathrm{~S}$ \\
Insulin/Glucose & 0.152 & 0.164 & 0.093 & 0.083 & $\mathrm{~S}$ \\
HOMA2IR \pm SD & $4.24 \pm 0.57$ & $4.31 \pm 0.59$ & $1.36 \pm 0.23$ & $1.18 \pm 0.13$ & $\mathrm{NS}$ \\
HOMA\%B \pm & $62.0 \pm 2.39$ & $69.5 \pm 2.24$ & $75.57 \pm 13.1$ & $85.05 \pm 9.19$ & $\mathrm{~S}$ \\
HOMA\%S & $23.60 \pm 3.90$ & $23.2 \pm 3.70$ & $80.80 \pm 12.46$ & $76.20 \pm 14.02$ & \\
\hline
\end{tabular}

Table 3. Levels of HOMA2-IR, BMI, glucose, HbA1c, insulin hormone and sex hormone in men and women of control and patients with NIDDM. The values are the Mean \pm SD.

\begin{tabular}{|c|c|c|c|c|c|c|c|c|}
\hline & & \multicolumn{5}{|c|}{ Type $2 \mathrm{DM} \mathrm{n}=50$} & \multirow{3}{*}{$\begin{array}{c}\text { Control } \mathrm{n}=50 \\
\text { Mean } \pm \text { SD }\end{array}$} & \multirow{3}{*}{ Significance $p$-value } \\
\hline & & \multirow{2}{*}{ Mean \pm SD } & \multirow[b]{2}{*}{ SE } & \multirow{2}{*}{ Range } & \multicolumn{2}{|c|}{ 95\% C.I } & & \\
\hline & & & & & Lower & Upper & & \\
\hline \multirow{2}{*}{ HOMA2-IR } & Men & $4.24 \pm 0.57$ & 0.11 & $2.85-4.29$ & 3.1228 & 5.3572 & $1.36 \pm 0.23$ & \multirow{2}{*}{$S$} \\
\hline & Women & $4.31 \pm 0.59$ & 0.12 & $2.91-4.31$ & 3.1536 & 5.4664 & $1.18 \pm 0.13$ & \\
\hline \multirow{2}{*}{ BMI kg/m ${ }^{2}$} & Men & $25.49 \pm 1.34$ & 0.26 & $25.3-27.52$ & 22.8636 & 28.1164 & $21.35 \pm 1.54$ & \multirow{2}{*}{ HS } \\
\hline & Women & $26.51 \pm 2.56$ & 0.52 & $25.7-27.67$ & 21.4884 & 31.5315 & $22.54 \pm 2.75$ & \\
\hline \multicolumn{2}{|l|}{ Glucose (mg/dl) } & $185 \pm 16.28$ & 2.3 & $150-215$ & 153.0912 & 216.9088 & $107 \pm 09$ & HS \\
\hline \multicolumn{2}{|l|}{$\mathrm{HbAl}_{\mathrm{C}} \%$} & $8.93 \pm 1.21$ & 0.17 & $7.1-11.3$ & 6.5584 & 11.3016 & $5.89 \pm 0.9$ & HS \\
\hline \multicolumn{2}{|l|}{ Insulin $(\mu \mathrm{U} / \mathrm{ml})$} & $29.15 \pm 5.51$ & 0.78 & $18.96-35.31$ & 18.3504 & 39.9496 & $9.70 \pm 1.59$ & HS \\
\hline \multirow{2}{*}{$\mathrm{FSH}(\mu \mathrm{U} / \mathrm{ml})$} & Men & $7.24 \pm 1.14$ & 0.22 & $5.4-9.70$ & 5.0056 & 9.4744 & $12.79 \pm 0.87$ & \multirow{2}{*}{$S$} \\
\hline & Women & $38.14 \pm 4.44$ & 0.90 & $32.10-47.20$ & 29.4376 & 46.8424 & $54.16 \pm 3.64$ & \\
\hline \multirow{2}{*}{$\mathrm{LH}(\mu \mathrm{U} / \mathrm{ml})$} & Men & $5.32 \pm 0.74$ & 0.14 & $4.20-6.80$ & 3.8696 & 6.7704 & $7.54 \pm 1.27$ & \multirow{2}{*}{$S$} \\
\hline & Women & $30.12 \pm 4.20$ & 0.85 & $23.30-38.10$ & 21.888 & 38.352 & $43.33 \pm 2.07$ & \\
\hline \multirow{2}{*}{$\mathrm{Tt}(\mathrm{ng} / \mathrm{ml})$} & Men & $4.69 \pm 0.92$ & 0.81 & $3.23-6.32$ & 2.8868 & 6.4932 & $8.20 \pm 2.2$ & \multirow{2}{*}{ HS } \\
\hline & Women & $0.57 \pm 0.11$ & 0.02 & $0.44-0.77$ & 0.3544 & 0.7856 & $0.69 \pm 0.21$ & \\
\hline \multirow{2}{*}{ Progesterone (ng/ml) } & Men & $0.25 \pm 0.03$ & 0.007 & $0.18-0.32$ & 0.1912 & 0.3088 & $0.42 \pm 0.10$ & \multirow{2}{*}{$S$} \\
\hline & Women & $0.30 \pm 0.04$ & 0.008 & $0.24-0.39$ & 0.2216 & 0.3784 & $0.46 \pm 0.12$ & \\
\hline \multirow{2}{*}{$\mathrm{E}_{2}(\mathrm{pg} / \mathrm{ml})$} & Men & $25.04 \pm 3.35$ & 0.65 & $20.0-31.4$ & 18.474 & 31.606 & $33.80 \pm 8.4$ & \multirow{2}{*}{$S$} \\
\hline & Women & $34.33 \pm 4.21$ & 0.86 & $25.0-43.6$ & 26.0784 & 42.5816 & $41.42 \pm 5.64$ & \\
\hline
\end{tabular}

\subsection{Levels of HOMA2-IR, BMI, Glucose, HbA1c, Insulin Hormone and Sex Hormone in Men and Women of Control and NIDDM Patients}

Results mention in (Table 3) show that is a significant increase in IR level (4.24 \pm 0.57 Vs. $1.36 \pm 0.23$ and $4.31 \pm 59$ Vs. $1.18 \pm 0.13, \mathrm{P}<0.05$ ), respectively, significantly increases in BMI level $(25.49 \pm 1.34$ Vs. $21.35 \pm 1.54$ and $26.51 \pm 2.562$ Vs. $\left.22.54 \pm 2.75 \mathrm{~kg} / \mathrm{m}^{2}, \mathrm{P}<0.01\right)$, and a highly significantly increases in serum glucose level $(185 \pm 16.28$ Vs. $107 \pm 9.52 \mathrm{mg} / \mathrm{dl}, \mathrm{P}<0.01)$ in NIDDM patients 
compared with control. Same Table 3 reflect the level of blood HbA1c \% with their significant increases $(8.93 \pm 1.21$ Vs. $5.89 \pm 0.90, \mathrm{P}<0.01)$ in NIDDM patients with compared to control. Furthermore, a significant increase $(\mathrm{P}<0.01)$ was seen in serum insulin hormone level in NIDDM subjects $(29.15 \pm 5.51$ $\mu \mathrm{U} / \mathrm{ml})$ compared with that of control $(9.70 \pm 1.59 \mu \mathrm{U} / \mathrm{ml})$. Moreover, data obtained in (Table 3) show a significant decrease in FSH level $(7.24 \pm 1.14 \mathrm{Vs}$. $12.79 \pm 0.87$ and $38.14 \pm 4.44$ Vs. $54.16 \pm 3.64 \mu \mathrm{U} / \mathrm{ml}, \mathrm{P}<0.05)$, a significant decrease in LH level $(5.32 \pm 0.74$ Vs. $7.54 \pm 1.27$ and $30.12 \pm 4.20$ Vs. $43.33 \pm 2.07$ $\mu \mathrm{U} / \mathrm{ml}, \mathrm{P}<0.05)$, a significant decrease in testosterone level $(4.69 \pm 0.92 \mathrm{Vs} .8 .20$ \pm 2.2 and $0.57 \pm 0.11$ Vs. $0.69 \pm 0.21 \mathrm{ng} / \mathrm{ml}, \mathrm{P}<0.01)$, a significant decrease in progesterone level $(0.25 \pm 0.03$ Vs. $0.42 \pm 0.10$ and $0.30 \pm 0.04$ Vs. $0.46 \pm 0.12$ $\mathrm{ng} / \mathrm{ml}, \mathrm{P}<0.05)$ and a significant decrease in estradiol level $(25.04 \pm 3.35$ Vs. $33.80 \pm 8.4$ and $34.33 \pm 4.21$ Vs. $41.42 \pm 5.64 \mathrm{pg} / \mathrm{ml}, \mathrm{p}<0.05)$ respectively, in men and women type 2 diabetic patients compared to control.

\subsection{Study the Correlation Analysis}

Correlation Coefficient ( $r$ ) between Insulin Resistance and Level of HbA1 1 , FSH, LH, Tt, Progesterone and Estradiol in NIDDM Patients

The present results confirmed that insulin resistance was positively and highly significantly correlated with level of $\mathrm{HbAl}_{\mathrm{C}}(\mathrm{r}=0.713, \mathrm{P}<0.01)$, a highly significantly correlated with level FSH $(\mathrm{r}=-0.430 ;-0.414, \mathrm{P}<0.01)$ and $\mathrm{LH}(\mathrm{r}=$ $-0.469 ;-0.480, \mathrm{P}<0.05)$, a negative and significantly correlated with level total testosterone $(\mathrm{r}=-0.541 ;-0.492, \mathrm{P}<0.01)$, negative and significantly correlated with level progesterone $(\mathrm{r}=-0.441 ;-0.369, \mathrm{P}<0.05)$, negative and significantly correlated with level estradiol $(r=-0.410 ;-0.448, \mathrm{P}<0.05)$ in men and women, as shown in Table 4 and Figures 1-5, respectively.

Table 4. Correlation coefficient ( $\mathrm{r}$ ) between the insulin resistance and some biochemical parameters $\left(\mathrm{HbAlc}, \mathrm{FSH}, \mathrm{LH}, \mathrm{Tt}\right.$, progesterone and $\mathrm{E}_{2}$ ) in NIDDM patients. The values are the Mean \pm SD.

\begin{tabular}{|c|c|c|c|}
\hline \multirow{2}{*}{\multicolumn{2}{|c|}{$\begin{array}{l}\text { The correlation of insulin resistance } \\
\qquad v s \text { other variables }\end{array}$}} & \multirow{3}{*}{$\begin{array}{c}\text { Type } 2 \mathrm{DM}, \mathrm{n}=50 \\
\text { Correlation coefficient (r) } \\
0.713\end{array}$} & \multirow{3}{*}{$\begin{array}{c}\begin{array}{c}\text { Significance } \\
\text { p-value }\end{array} \\
\text { HS }\end{array}$} \\
\hline & & & \\
\hline Vs. $\mathrm{HbAl}_{\mathrm{C}} \%$ & Total Patients & & \\
\hline \multirow{2}{*}{$V s . \mathrm{FSH}(\mu \mathrm{U} / \mathrm{ml})$} & Men & -0.430 & S \\
\hline & Women & -0.414 & $S$ \\
\hline \multirow{2}{*}{$V s . \mathrm{LH}(\mu \mathrm{U} / \mathrm{ml})$} & Men & -0.469 & S \\
\hline & Women & -0.480 & S \\
\hline \multirow{2}{*}{$V s . \mathrm{Tt}(\mathrm{ng} / \mathrm{ml})$} & Men & -0.541 & HS \\
\hline & Women & -0.492 & HS \\
\hline \multirow{2}{*}{ Vs. Progesterone (ng/ml) } & Men & -0.441 & S \\
\hline & Women & -0.369 & S \\
\hline \multirow{2}{*}{ Vs. $\mathrm{E}_{2}(\mathrm{pg} / \mathrm{ml})$} & Men & -0.410 & $S$ \\
\hline & Women & -0.448 & S \\
\hline
\end{tabular}




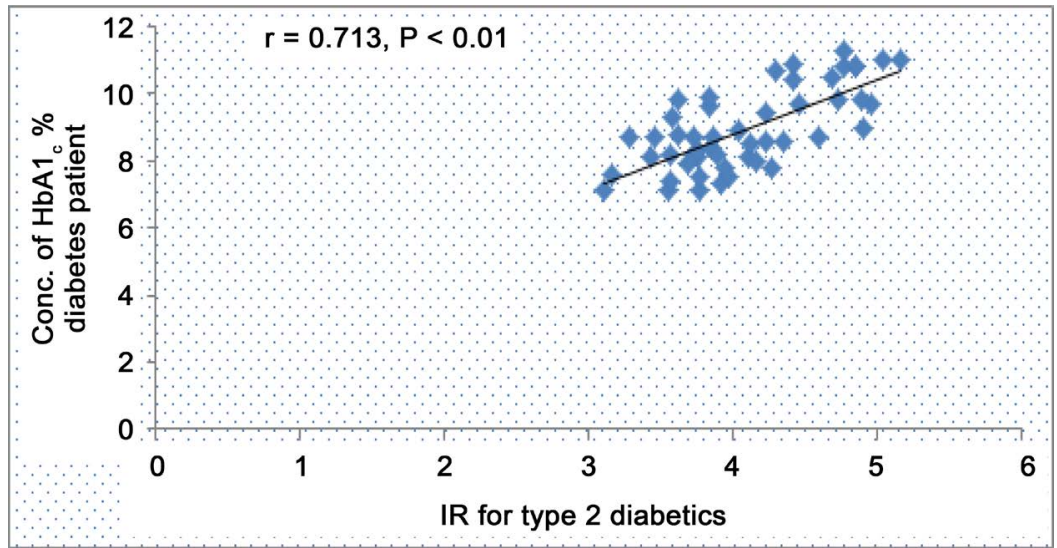

Figure 1. Correlation coefficient (r) of insulin resistance (IR) with level of $\mathrm{HbAl}_{\mathrm{C}} \%$ in blood of NIDDM patients.

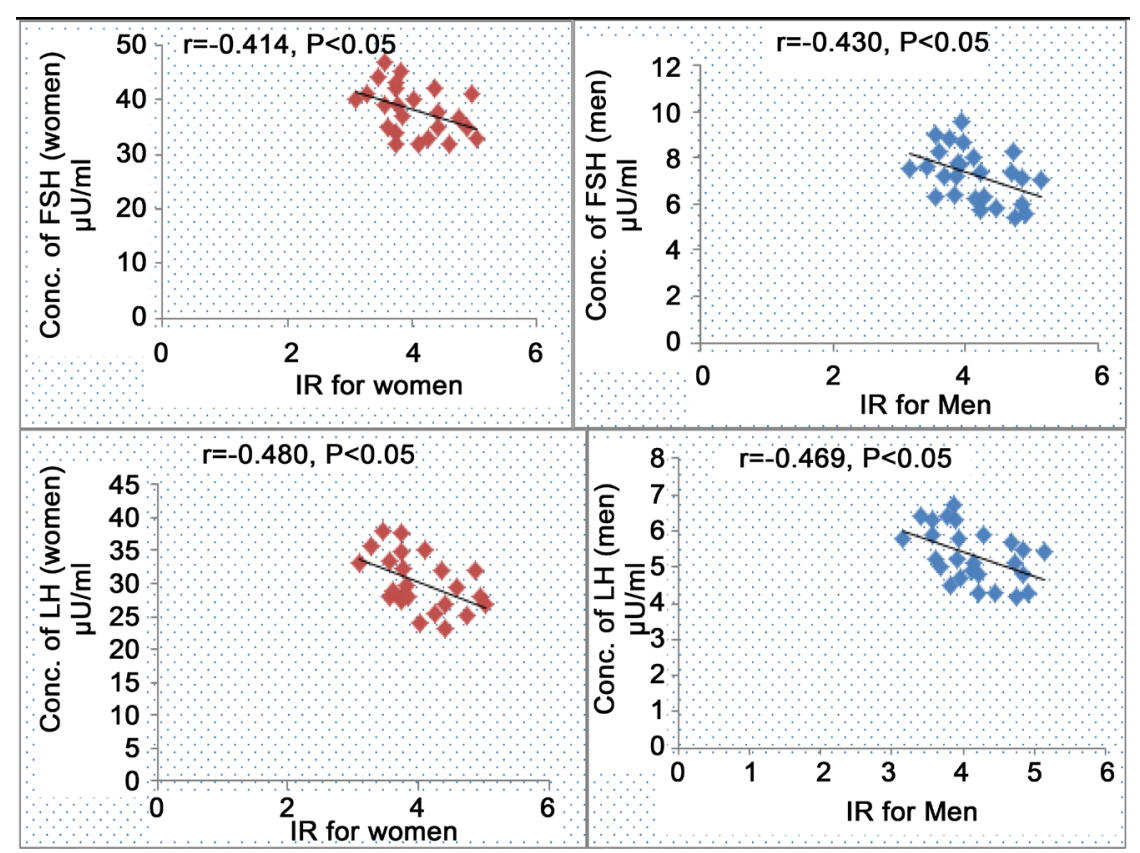

Figure 2. Correlation coefficient (r) of insulin resistance (IR) with level of FSH and LH in serum of NIDDM patients.

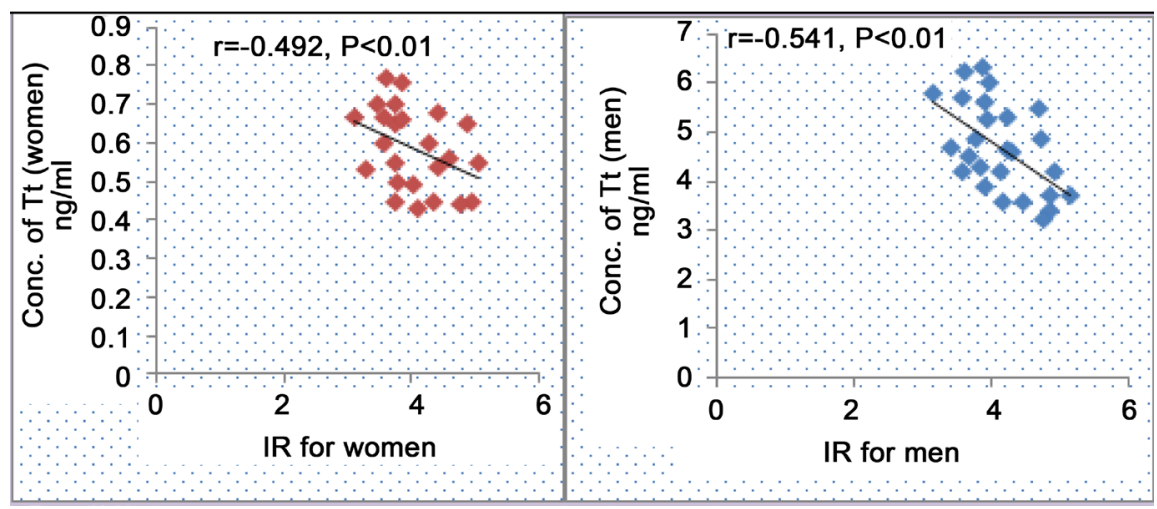

Figure 3. Correlation coefficient ( $r$ ) of insulin resistance (IR) with level of testosterone in serum of NIDDM patients. 


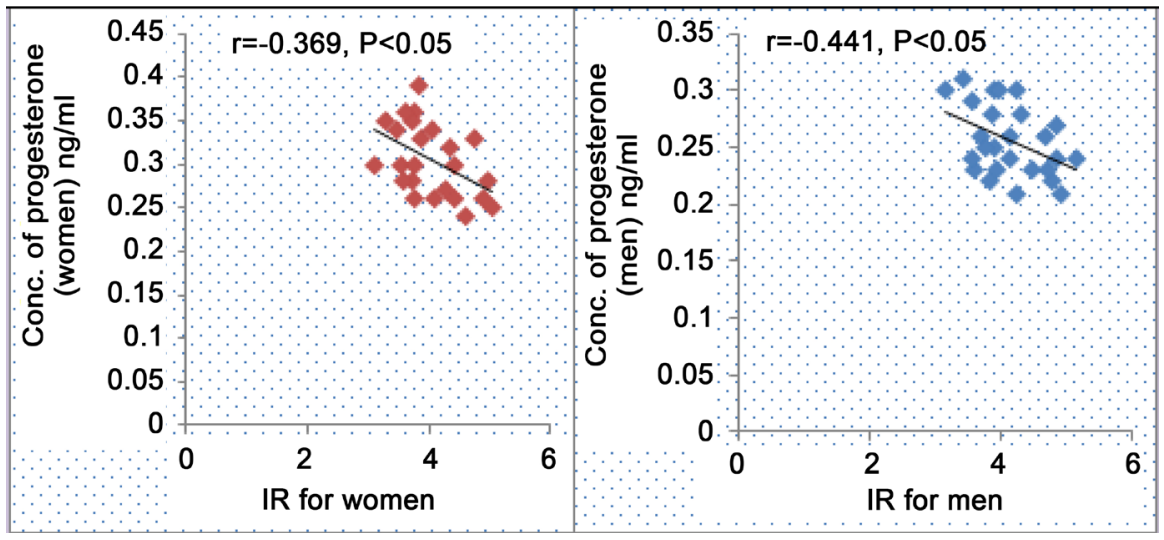

Figure 4. Correlation coefficient (r) of insulin resistance (IR) with level of progesterone in serum of NIDDM patients.

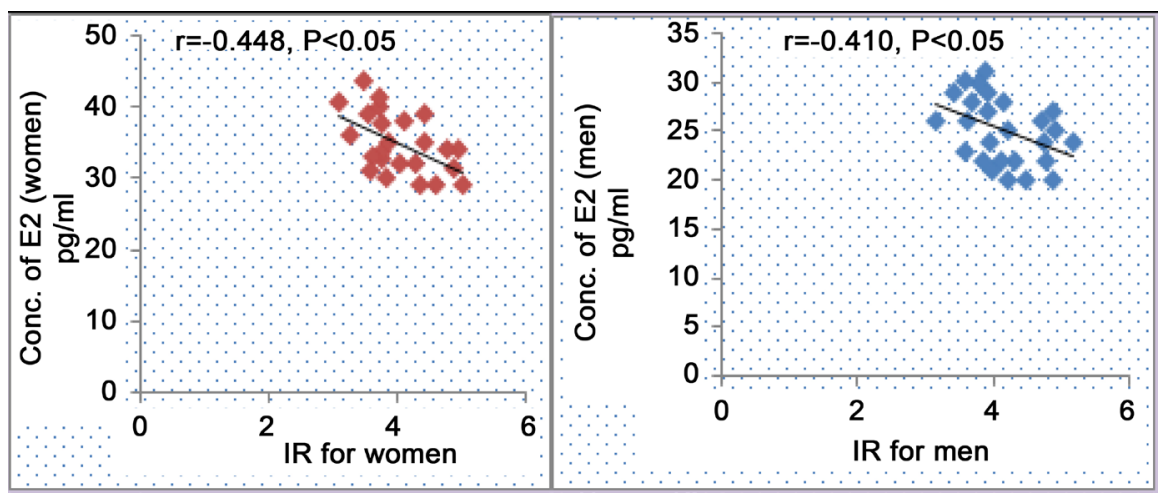

Figure 5. Correlation coefficient (r) of insulin resistance (IR) with level of estradiol in serum of NIDDM patients.

\section{Discussion}

Fluctuations of glucose occur in all time and one of the effective ways is to monitor the $\mathrm{HbAlc}$, which gives the level average of blood glucose at the preceding of 2 - 3 months. In epidemiological studies, $\mathrm{HbA1c}$ will be a valuable adjunct to blood glucose determinations. Various studies prove that the amount of carbohydrate attached to the $\mathrm{HbAlc}$ increases with increasing duration of the disease. On the other hand, the body becomes more resistant to insulin hormone with increasing in the duration of diabetes; so that the level of insulin hormone is normal or high in the body but insufficient in the availability of insulin [18]. As recently pointed out in a study, due to the feedback between glucose concentration (the major stimulus for insulin release) and insulin secretion from $\beta$-cell, it is virtually impossible to develop diabetes due to severity of insulin resistance found in most NIDDM patients unless the capacity to secrete additional amounts of insulin to compensate for the insulin resistance is impaired [19]. In this work, we found a positive correlation between insulin resistance and HbA1c level which is may be due to the elevated level of insulin resistance, decreased activity of insulin hormone lead to hyperglycemia which causing increased glycation of hemoglobin and increased release of free iron from glycated proteins like 
hemoglobin. This makes a vicious cycle of hyperglycemia, glycation of hemoglobin and increase in levels of free iron and ferritin. This increased presence of iron pool will enhance oxidant generation leading damage to biomolecules. These results go with the result of [20]. On the other hand, increased accumulation of iron affects insulin synthesis and its secretion from the pancreas and interferes with the insulin-extracting capacity of the liver. Iron deposition in muscle decreases glucose uptake because of muscle damage [21]. The correlation between hyperglycemia, BMI, insulin resistance and hypogonadotrophins (FSH and LH) in diabetes mellitus are complex. It is commonly accepted that the volume of the fat mass increases with age results into the higher BMI noted during some diseases such as diabetes [22]. While hypothalamic-pituitary function decreased with age, increased BMI and insulin resistance, the presence of diabetes had aggravated this defect, FSH and LH production was more affected in patients with DM. Also, insulin resistance can lead to compensatory hyperinsulinemia, where the body attempts to balance the reduced effects of insulin by producing and releasing more insulin [23]. Therefore, the inverse correlation between insulin resistance and levels of (FSH and $\mathrm{LH}$ ) in the present work is may be due to continuous free radical production with advancing age of type 2 diabetic patients, and supports the hypothesis of radical mediated injury in this disease. Evidence from clinical studies suggests that oxidative stress plays a role in the etiology of adverse reproductive events in both women and men. An imbalance between reactive oxygen species (ROS) and antioxidant actions result in oxidative stress. Diabetes mellitus on normal cellular processes has marked effects which resulting in dysregulated mitochondrial free radical production and disparity between generation of reactive oxygen species and antioxidant defenses, leading to diminished gonadotrophin and anti-steroidogenic actions, DNA damage, and inhibited protein ATP production. Thus the diminished levels of both gonadotrophins ( $\mathrm{LH}$ and FSH) may be attributed to increased ROS generation which can cause impairment in its production and secretion [24]. The greater concentrations of free radicals found in diabetics are due to increased glucose auto-oxidation [25]. The free radicals are secondary species derived from decomposition of lipid hydroperoxides. The study shows that diabetic men are exposed to elevated oxidative stress. It is reported that increased oxidative stress is a well-accepted mechanism of tissue injury [22]. On the other hand, obesity/insulin resistance is associated with hypogonadism through increased plasma levels of pro-inflammatory cytokines, such as TNF alpha, IL-1 and IL-6, C-reactive protein, and adhesion molecules which it produced by visceral adipocytes [26]. This result may be due to the increased abdominal obesity, higher BMI which leads to increase aromatase activity (enzyme present in fat tissues) and hence more testosterone is converted to estradiol, this lower level of testosterone may lead to increase activity of lipoprotein lipase, causing an increased fatty acid uptake and triacylglycerol storage in adipocytes [27]. On the other hand, insulin resistance, acting through signs mediated by the adipose tis- 
sue, including increased levels of adepokins, would have a direct role in the regulation of gonadal function, thus decreasing the concentrations of testosterone [28]. Consequently in diabetic men, in addition to decreased testosterone production and metabolism, higher than normal percentages of testosterone and androstenedione are converted into estradiol and estrone, respectively. This increased conversion may account for the diminished testosterone [29]. The question thus arises as to why diabetic men have lower testosterone levels; the answer was Klinefelter's syndrome, the most frequent form of primary hypogonadism, is associated with insulin resistance and diabetes [30]. Recent studies were found that free testosterone was diminished in diabetic patients with organic importance. This is not found in the non-impotent diabetes. Male impotence which consists in difficulty in obtaining or maintaining full erection until the end of coitus is a common sexual problem in diabetics [31]. Hyperinsulinaemia, as encountered in insulin resistance, might impair testosterone secretion by the leydig cell may be directly since there are insulin receptors on the Leydig cells. It has also been found in obese men that there is an attenuated pulse amplitude of luteinizing hormone (LH), thus producing a less strong stimulation of testicular testosterone production [32]. In the present study, decreased level of progesterone in diabetic patients might be result from increased level of insulin resistance. Also, because hyperglycemia elevated BMI in diabetes can causes a decrease in serum levels of FSH and LH, which is accompanied by a loss of sensitivity of ovarian cells to these two hormones [24]. Impaired action of FSH and LH on the ovary has, as a primary consequence, a concomitant alteration in the capacity of this organ to synthesize ovarian reproductive hormones; mainly estradiols from follicular cells and progesterone from luteal cells [33]. Moreover, in diabetic patients, hyperglycaemia develops but no glucose can enter into the cell of the insulin target tissues. This cellular stress may involve mitogen-activated protein kinase activation in the various tissues explored including the ovary despite it not being considered to be a major insulin-dependent tissue. The increase in mitogen-activated protein kinase activation in the ovary of diabetic patients may contribute to the decrease in progesterone secretion [34]. In this work, the negative correlation between insulin resistance and estradiol may be due to the importance role of E2 in protecting against insulin resistance and diabetes. Estradiol (E2) is involved in the maintenances of normal insulin sensitivity at physiological levels. On the other hand, estradiol in outside the physiological range may promote insulin resistance and diabetes [35]. Also, it has been reported that women with low serum levels of estrogens are at higher risk of developing type-2 diabetes mellitus [36]. Furthermore, both of insulin resistance and estrogen deficiency result in complex metabolic disorder based mainly on defective cellular glucose uptake and on an atherogenic serum lipid profile. These alterations may be regarded as high risks for several life-threatening human diseases, such as type-2 diabetes, cardiovascular lesions and malignancies. IR and the compensatory hyperinsulinemia provoke increased androgen synthesis at the expense of 
decreased estrogen production. Moreover, loss of estrogen function has been shown to cause insulin resistance in male patients with type 2 diabetes mellitus. E2 may regulate insulin action directly via actions on insulin-sensitive tissues or indirectly by regulating factors like oxidative stress, which contribute to insulin resistance [37]. It has been suggested that obese patients with insulin resistance have a diminished sensitivity to insulin action in the hypothalamus-pituitarygonadal axis due to the production of cytokines and hormones by the adipose tissue [38].

\section{Conclusion}

In our study, we have shown that an increase in level of insulin resistance is associated with increased level of blood HbAlc and decreased in levels of serum sex hormones (FSH, LH, Tt, E2 and progesterone) in men and women of diabetic group. These behaviors might suggest that insulin resistance can be used as a potential biomarker for predicting dysfunction of sex hygiene in NIDDM patients in addition to glycemic control.

\section{Acknowledgements}

Author is highly thankful to the head of Chemistry Department, College of Science, University of Basrah for providing their kind support and facilities to accomplish the present research project within time.

\section{References}

[1] Rother, K.I. (2007) Diabetes Treatment-Bridging the Divide. The New England Journal of Medicine, 356, 1499-1501. https://doi.org/10.1056/NEJMp078030

[2] Vinay, K., Abul, K.A. and Nelson, F. (1999) Robbins Pathologic Basis of Disease, 6th Edition, Elsevier Inc., Philadelphia, 913-926.

[3] Burtis, C.A., Ashwood, E.R. and Bruns, D.E. (2008) Tietz Textbook of Clinical Chemistry and Molecular Diagnostics. Reed Elsevier, India, 854-900.

[4] Dhindsa, S., Prabhakar, S., Sethi, M., Bandyopadhyay, A., Chaudhuri, A. and Dandona, D. (2005) Frequent Occurrence of Hypogonadism in Type 2 Diabetes. The Journal of Clinical Endocrinology \& Metabolism, 90, 1903. https://doi.org/10.1210/jc.2004-2469

[5] Moisa, S.S. (2017) Calcitonin Participant in the Development of Insulin Resistance. Journal of Biomedical Science and Engineering, 10, 343-354. https://doi.org/10.4236/jbise.2017.107026

[6] Ding, E.L., Song, Y., Malik, V.S. and Liu, S. (2006) Sex Differences of Endogenous Sex Hormones and Risk of Type 2 Diabetes: A Systemic Review and Metaanalysis. $J A M A, 295,1288-1299$. https://doi.org/10.1001/jama.295.11.1288

[7] Stanciu, I., Abboud, A., Kellman, W., Williams, D. and Azad, N. (2010) Correlation of Aging and Body Mass Index with the Hypothalamic-Pituitary-Gonadal Axis Hormones in Men, with Diabetes Mellitus. The Open Andrology Journal, 2, 6-10. https://doi.org/10.2174/1876827X01002010006

[8] Chandalia, H.B. and Krishnaswamy, P.R. (2008) Glycated Hemoglobin. Current Science, 83, 1522-1532. 
[9] Sumesh Raj, G. and Rajan,V. (2013) Correlation between Elevated Serum Ferritin and HbAlc in Type 2 Diabetes Mellitus. International Journal of Research in Medical Sciences, 1, 12-15. https://doi.org/10.5455/2320-6012.ijrms20130203

[10] Trinder, P. (1969) Determination of Glucose in Blood Using Glucose Oxidase with an Alternative Oxygen Receptor. Annals of Clinical Biochemistry, 6, 24-27. https://doi.org/10.1177/000456326900600108

[11] Judzewitsch, R.G., Pfeifer, M.A., Best, J.D., Beard, J.C., Helter, J.B. and Porte, D.J. (1982) Chronic Chlorpropamide Therapy of Noninsulin-Dependent Augments Basal and Stimulated Insulin Secretion Islet Sensitivity to Glucose. The Journal of Clinical Endocrinology \& Metabolism, 55, 321-328. https://doi.org/10.1210/jcem-55-2-321

[12] Abraham, E.C., Huff, T.A., Cope, N.D., Wilson, J.B., Bransome, E.D. and Huisman, T.H. (1978) Determination of the Glycosylated Hemoglobins with a New Microcolumn Procedure. Suitability of the Technique for Assessing the Clinical Management of Diabetes Mellitus. Diabetes, 27, 931-937.

https://doi.org/10.2337/diab.27.9.931

[13] Odell, W.D. and Parlow, A.F. (1981) Estimation of FSH Test Assay. Journal of Clinical Investigation, 47, 2551. https://doi.org/10.1172/JCI105937

[14] Kosase, T.S. (1981) Measurement of Human Luteinizing Hormone. Journal of Reproductive Medicine, 26, 201-206.

[15] Kicklighter, E.J. and Norman, R.J. (1989) The Gonads. Clinical Chemistry, 43, 658-660.

[16] Hahlin, M., Wallin, A., Sjöblom, P. and Lindblom, B. (1990) Single Progesterone Assay for Early Recognition of Abnormal Pregnancy. Human Reproduction, 5, 622-626. https://doi.org/10.1093/oxfordjournals.humrep.a137157

[17] Wramsby, H., Sundstrom, P. and Liedholm, P. (1987) Pregnancy Rate in Relation to Number of Cleaved Eggs Replaced after in Vitro Fertilization in Stimulated Cycles Monitored by Serum Levels of Oestradiol and Progesterone as Sole Index. Human Reproduction, 2, 325-328.

[18] Mayumi, O., Seiji, N., Yoko, I., Eiko, Y., et al. (2003) Effects of Post-Menopausal Hormone Replacement Therapy on HbA1c Levels. Diabetes Care, 26, 1088-1092. https://doi.org/10.2337/diacare.26.4.1088

[19] Verma, M., Paneri, S., Badi, P. and Raman, P.G. (2006) Effect of Increasing Duration of Diabetes Mellitus Type 2 on Glycated Hemoglobin and Insulin Sensitivity. Indian Journal of Clinical Biochemistry, 21, 142-146. https://doi.org/10.1007/BF02913083

[20] Maheshwari, A.V., Bhoi, B.K., Sadariya, B.R., Javia, H.N., Gusani, J.K. and Sharma, H. (2015) Correlation between Serum Ferritin and Glycaemic Control in Patients of Type 2 Diabetes Mellitus: A Case Control study. International Journal of Research in Medical Sciences, 3, 2327-2330. https://doi.org/10.18203/2320-6012.ijrms20150625

[21] Fernandez-Real, J.M., Penarroja, G., Castro, A., Garcia-Bragado, F., Hernandez-Aguado, I. and Ricart, W. (2002) Blood Letting in High-Ferritin Type 2 Diabetes. Effects on Insulin Sensitivity and Beta-Cell Function. Diabetes, 51, 1000-1004. https://doi.org/10.2337/diabetes.51.4.1000

[22] Maneesh, M., Jayalekshmi, H., Dutta, S., Amit, C. and Vasudevan, D.M. (2005) Effect of Chronic Ethanol Administration on Testicular Antioxidant System and Steroidogenic Enzyme Activity in Rats. Indian Journal of Experimental Biology, 43, 445-449. 
[23] Suga, N., Gao, E., Zhang, Y., Ma, X. and Olsen, J.F. (2000) The Corticofugal System for Hearing: Recent Progress. Proceedings of the National Academy of Sciences, 97, 11807-11814. https://doi.org/10.1073/pnas.97.22.11807

[24] Khowailed, A., Mohammad, O., Elattar, S. and Gaber, S. (2012) Effect of Sildenafil on Gonadotrophin and Sex Steroids in Fructose Induced Diabetes in Female Rats. The Medical Journal of Cairo University, 80, 243-252.

[25] Shah Siddharth, N. (2000) Alpha Lipic Acid in Diabetes. Journal of Diabetology, 12, 17.

[26] Corrales, J.J., Almeida, M., Burgo, R., Mories, M.T., Miralles, J.M. and Orfao, A. (2006) Androgen-Replacement Therapy Depresses the ex Vivo Production of Inflammatory Cytokines by Circulating Antigen-Presenting Cells in Aging Type-2 Diabetic Men with Partial Androgen Deficiency. Journal of Endocrinology, 189, 595-604. https://doi.org/10.1677/joe.1.06779

[27] Shahin, E.B.A., Hilmyb, K.M.H. and Assarc, M.F.A. (2015) The Association of Serum Testosterone and Sex Hormone-Binding Globulin with Obese Men and Type 2 Diabetic Men. American Journal of Research Communication, 3, 97-108.

[28] Chan, J.L., Heist, K., DePaoli, A.M., Veldhuis, J.D. and Mantzoros, C.S. (2003) The Role of Falling Leptin Levels in the Neuroendocrine and Metabolic Adaptation to Shortterm Starvation in Healthy Men. The Journal of Clinical Investigation, 111, 1409-1421. https://doi.org/10.1172/JCI200317490

[29] Maneesh, M., Jayalakshim, H., Singh, T.A. and Chakrabarti, A. (2006) Impaired Hypothalamic-Pituitary-Gonadal Axis Function in Men with Diabetes Mellitus. Indian Journal of Clinical Biochemistry, 21, 165-168. https://doi.org/10.1007/BF02913088

[30] Ota, K., Suehiro, T., Ikeda, Y., Arii, K., Kumon, Y. and Hashimoto, K. (2002) Diabetes Mellitus Associated with Klinefelter's Syndrome: A Case Report and Review in Japan. Internal Medicine, 41, 842-847. https://doi.org/10.2169/internalmedicine.41.842

[31] De-Berardis, G., Pellegrini, F., Franciosi, M., Belfiglio, M., Di Nardo, B., Greenfield, S., Kaplan, S.H., Rossi, M.C.E., Sacco, M., Togno, G., Valentini, M. and Nicolucci, A. (2007) Clinical and Psychological Predictors of Incidence of Self-Reported Erectile Dysfunction in Patients with Type 2 Diabetes. The Journal of Urology, 177, 252-257.

[32] Alhammer, A.H. (2015) Study the Association of Testosterone Levels with Insulin Resistance in Iraqi Men with Diabetes Mellitus Type 2. Journal of Biotechnology Research Center, 9, 4-12.

[33] Amaral, S., Moreno, A.J., Santos, M.S., Seica, R. and Ramalho-Santas, J. (2006) Affects of Hyperglycemia on Sperm and Testicular Cells of Goto-Kakizaki and Strep-Tozotocin-Treated Rat Models for Diabetes. Theriogenology, 66, 2056-2067.

[34] Tosal, L., Froment, P., Solnais, P., Ferre, P., Foufelle, F. and Dupont, J. (2005) Adenosine 5'-Monophosphate-Activated Protein Kinase Regulates Proges-Terone Secretion in Rat Granulosa Cells. Endocrinology, 146, 4500-4513. https://doi.org/10.1210/en.2005-0301

[35] Godsland, I.F. (2005) Oestrogens and Insulin Secretion. Diabetologia, 48, 2213-2220. https://doi.org/10.1007/s00125-005-1930-0

[36] Livngstone, C. and Collison, M. (2002) Sex steroids and Insulin Resistance. Clinical Science, 102, 151-166. https://doi.org/10.1042/cs1020151

[37] Barros, R.P.A., Gabbi, C., Morani, A., Warner, M. and Gustafsson, J.A. (2009) Participation of $\mathrm{ER} \alpha$ and $\mathrm{ER} \beta$ in Glucose Homeostasis in Skeletal Muscle and White 
Adipose Tissue. American Journal of Physiology_Endocrinology and Metabolism, 297, E124-E133. https://doi.org/10.1152/ajpendo.00189.2009

[38] Pitteloud, N., Hardin, M., Dwyer, A.A., Valassi, E., Yialamas, M., Elahi, D., Yialamas, M., Elahi, D. and Frances, J. (2005) Increase Insulin Resistance Is Associated with a Decrease in Leydig Cell Testosterone Secretion in Men. The Journal of Clinical Endocrinology \& Metabolism, 90, 2636-2646.

https://doi.org/10.1210/jc.2004-2190 